\title{
New Insights in Microchimerism: New Topic for Our Journal?
}

\author{
Serge Uzan Sélim Aractingi \\ Service de gynécologie-obstétrique et unité de dermatologie, Hôpital Tenon (APHP), et UPRES EA 2396 \\ (Physiologie de I'Implantation et du Développement, UFR St-Antoine, Paris VI), France
}

Concern, reflections and hypotheses about feto-maternal relationships have probably been emerging for as long as philosophers and scientists have existed. The peculiar links between a mother and her fetus have fascinated intellectuals in very diverse fields. Besides, as all readers of this journal know very well, more academic studies have widely focused on this subject. The fetal consequences of maternal diseases, such as infections, thyroid or cardiac abnormalities have been well described during last decades. In the same way, the maternal consequences of pregnancy, such as worsening of lupus erythematosus and multiple sclerosis, or triggering of diabetes, have also been the field of large studies. Finally, preeclampsia has been at the center of multiple specialties and appears to result from abnormalities in the early relationship between fetal-maternal tissues. Beside these known phenomenons, new insights into fetal-maternal relationships have come from studies devoted to microchimerism. Recent papers as well as recent meetings held in Paris (Oct 1999) and Detroit (July 2000) devoted to this subject have drawn interest to this phenomenon. Microchimerism is defined by the presence in an individual of a very low level of cells originating from another individual [1]. Besides pregnancy, which appears to be the most frequent source for microchimerism, other conditions may result in microchimerism. These are mainly solid-organ transplanta- tions [2, 3] and red blood cell transfusions [4, 5]. Microchimerism resulting from feto-maternal trafficking during pregnancy has also been very well known since the late 1960s, the more sophisticated studies being done after the polymerase chain reaction (PCR) tool was discovered and used to amplify Y-positive cells in the blood of females bearing male fetuses [6, 7]. Interestingly, Bianchi et al. [8] recently showed that fetal cells could persist in the circulating blood of women up to 27 years after delivery, opening new perspectives for the fate and the role of microchimerism. These were hemopoietic CD34+ stem cells. In a reverse way, maternal cells may also migrate into fetuses. The first evidence for this materno-fetal trafficking came from cord blood analysis. Since marrow transplantation using cord blood gave a low incidence of graft-versus-host diseases (GvHD), several groups have analyzed this tissue and surprisingly found that maternal cells were present in it $[9,10]$. In addition, maternal cells were detected in children with immunodeficiencies, and were able to determine GvHD in some [11]. Finally, findings from a recent publication demonstrated that in up to nearly $50 \%$ of normal adults, circulating maternal cells - picked up by PCR targeting of non-shared maternal HLA alleles - were found [12]. Therefore all these studies go far from the classical view of fetal cell transfer in the mother's blood during pregnancy, since we now know that fetal and maternal

\footnotetext{
KARGER

Fax +4161306 1234

E-Mail karger@karger.ch www. karger.com

(c) 2000 S. Karger AG, Basel

1015-3837/00/0156-0319\$17.50/0

Accessible online at:

www. karger.com/journals/fdt
} 
cells may persist for decades in the blood - and maybe in tissues - of mothers and children.

Besides these findings, investigators working in rheumatology hypothesized that some autoimmune diseases, predominating in females and for whom similar features may develop in GvHD, could result from allogeneic cells [13]. Taking advantage of the fact that fetal cells are able to persist for years, Nelson et al. [14] showed that the level of fetal cells was higher in women with scleroderma than in control women. In addition, HLA class-II analysis demonstrated that compatibility of the child's tissues from the mother's perspective was more frequently found in families with scleroderma $[14,15]$, this type of situation being known to favor post-transfusional GvHD. Artlett et al. $[16,17]$ obtained similar results, also showing that the fetal circulating cells in women with scleroderma were $\mathrm{T}$ and/or monocytes. All these original data led to the development of a new concept in the feto-maternal relationship, namely that fetal cells may be responsible for deleterious immune events in the mother years after delivery. However, soon after, other studies emphasized that microchimerism could frequently be found in normal individuals, in different lymphocytic subpopulations [18]. As microchimerism is statistically associated with the development of some autoimmune diseases, this phenomenon is probably not able to act alone, but is rather part of a multistep phenomenon. Other autoimmune diseases predominating in women will certainly be the field of studies evaluating the role of microchimerism.

Other new data concerning microchimerism were devoted to pregnancy. The group in Basel has interestingly found that the level of fetal cells was increased during preeclampsia [19]. The increased fetal cells were nucleated erythroblasts [19]. This disturbed trafficking of fetal cells into the maternal periphery with preeclampsia may be secondary to placental abnormalities, but may itself play a role once it has appeared. These findings of disturbed trafficking are in accordance with very old data showing that trophoblast cells could be found in the lungs of women with preeclampsia. We have shown that fetal DNA could be found in the skin lesions of polymorphic eruptions of pregnancy, raising the hypothesis that during pregnancy fetal cells may induce inflammatory reactions [20]. Finally, Lo et al. [21] were the first to demonstrate a very original finding, namely the presence of free fetal DNA in the mother's serum and plasma. The level of this free DNA is very high, increases throughout pregnancy and disappears within $2 \mathrm{~h}$ after delivery [22]. Similar to fetal cells, the fetal free DNA level in pregnant women is higher in preeclampsia and aneuploid pregnancies [23, 24]. The significance of the presence of this material remains unknwown. However, picking this material may allow noninvasive prenatal diagnosis close to what many groups evaluate on fetal circulating cells [25, 26]. Indeed, multiplex PCR on fetal DNA in plasma allowed almost $100 \%$ Rhesus D and sex evaluation. Of note, free donor DNA has also been demonstrated in solid organ transplantation [27].

This large amount of information opens many questions concerning the future of microchimerism. What are the factors which influence the prolonged establishment of such trafficking? What cells traffic and into which tissues? What drives microchimerism to pathological consequences? Is free fetal DNA transcripted and translated? All these interesting questions will probably stimulate future research programs. Knowledge of fetal-maternal interactions will hopefully increase. The maternal consequences of these interactions, which appear to be larger and later than previously thought, will most probably constitute a new topic for this journal.

\section{References}

1 Aractingi S, Uzan S, Dausset J, Carosella ED: Microchimerism in human diseases. Immunol Today 2000;21:116-118.

2 Starzl TE, Demetris AJ, Trucco M, Ramos H, Zeevi A, Rudert WA, Kocova M, Ricordi C, Ildstadt S, Murase N: Systemic chimerism in human female recipients of male livers. Lancet 1992;340:876-877.

3 Suberbielle C, Caillat-Zucman S, Legendre C, Bodemer C, Noel LH, Kreis H, Bach JF: Peripheral microchimerism in long term cadaveric kidney allograft recipients. Lancet 1994;343: 1468-1469.
4 Lee TH, Paglieroni T, Ohto H, Holland PV, Busch MP: Survival of donor leukocyte subpopulations in immunocompetent transfusion recipients: Frequent long-term microchimerism in severe trauma patients. Blood 1999;93: 3127-3139.

5 Carter AS, Cerundolo L, Bunce M, Koo DD, Welsh KI, Morris PJ, Fuggle SV: Nested polymerase chain reaction with sequence-specific primers typing for HLA-A, -B, and -C alleles: Detection of microchimerism in DR-matched individuals. Blood 1999;94:1471-1477.
6 Lo YM, Patel P, Wainscoat JS, Sampietro M, Gilmer MDG, Fleming KA: Prenatal sex determination by DNA amplification from maternal peripheral blood. Lancet 1989;ii:1363-1365.

7 Liou JD, Pao CC, Hor JJ, Kao SM: Fetal cells in the maternal circulation during first trimester in pregnancies. Hum Genet 1993;92:309311.

8 Bianchi DW, Zickwolf G, Weil G, Sylvester S, DeMaria MA: Male fetal progenitor cells persist in maternal blood for as long as 27 years postpartum. Proc Natl Acad Sci USA 1996;93: $705-770$. 
9 Hall JM, Lingenfelter P, Adams SL, Lasser D, Hansen JA, Bean MA: Detection of maternal cells in human umbilical cord blood using fluorescence in situ hybridization. Blood 1995;86: 2829-2832.

10 Socie G, Gluckman E, Carosella E, Brossard Y, Lafon C, Brison O: Search for maternal cells in human umbilical cord blood by polymerase chain reaction amplification of two minisatellite sequences. Blood 1994;83:340-344.

11 Appleton AL, Curtis A, Wilkes J, Cant AJ: Differentiation of materno-fetal GVHD from Omenn's syndrome in pre-BMT patients with severe combined immunodeficiency. Bone Marrow Transplant 1994;14:157-159.

12 Maloney S, Smith A, Furst DE, Myerson D, Rupert K, Evans PC, Nelson JL: Microchimerism of maternal origin persists into adult life. $\mathrm{J}$ Clin Invest 1999;104:41-47.

13 Nelson JL: Maternal-fetal immunology and autoimmune disease: Is some autoimmune disease auto-alloimmune or allo-autoimmune? Arthritis Rheum 1996;39:191-194.

14 Nelson JL, Furst DE, Maloney S, Gooley T, Evans P, Smith A, Bean MA, Ober C, Bianchi D: Microchimerism and HLA compatible relationships of pregnancy in scleroderma. Lancet 1998;351:559-562.
15 Artlett CM, Welsh KI, Black CM, Jimenez SA: Fetal-maternal HLA compatibility confers susceptibility to systemic sclerosis. Immunogenetics 1997; 47:17-22.

16 Artlett CM, Smith JB, Jimenez SA: Identification of fetal DNA and cells in skin lesions. N Engl J Med 1999;338:1186-1191.

17 Artlett CM, Cox LA, Jimenez SA: Detection of cellular microchimerism of male or female origin in systemic sclerosis patients by polymerase chain reaction analysis of HLA-Cw antigens. Arthritis Rheum 2000;43:1062-1067.

18 Evans PC, Lambert N, Maloney S, Furst DE, Moore JM, Nelson JL: Long-term fetal microchimerism in peripheral blood mononuclear cell subsets in healthy women and women with scleroderma. Blood 1999;93:2033-2037.

19 Holzgreve W, Ghezzi F, Di Naro E, Ganshirt D, Maymon E, Hahn S: Disturbed feto-maternal cell traffic in preeclampsia. Obstet Gynecol 1998;9:669-672.

20 Aractingi S, Berkane N, Bertheaux P, LeGoué C, Dausset J, Uzan S, Carosella ED: Fetal DNA in skin of polymorphic eruptions of pregnancy. Lancet 1998;352:1898-1901.

21 Lo YM, Corbetta N, Chamberlain PF, Rai V, Sargent IL, Redman CW, Wainscoat JS: Presence of fetal DNA in maternal plasma and serum. Lancet 1997;350:485-487.
22 Lo YM, Zhang J, Leung TN, Chang AM, Hjelm AN: Rapid clearance of fetal DNA from maternal plasma. Am J Hum Genet 1999;64:218224.

23 Lo YM, Lau TK, Zhang J, Leung TN, Chang AM, Hjelm NM, Elmes RS, Bianchi DW: Increased fetal DNA concentrations in the plasma of pregnant women carrying fetuses with trisomy. Clin Chem 1999;45:1747-1751.

24 Lo YM, Leung TN, Tein MS, Sargent IL, Zhang J, Lau TK, Haines CJ, Redman CW: Quantitative abnormalities of fetal DNA in maternal serum in preeclampsia. Clin Chem 1999;45:184-188.

25 Lo YM, Hjelm NM, Fidler C, Sargent IL, Murphy MF, Chamberlain PF, Poon PM, Redman CW, Wainscoat JS: Prenatal diagnosis of fetal RhD status by molecular analysis of maternal plasma. N Engl J Med 1998;339:1734-1738.

26 Zhong XY, Holzgreve W, Hahn S: Detection of fetal Rhesus D and sex using fetal DNA from maternal plasma by multiplex polymerase chain reaction. BJOG 2000;107:766-769.

27 Zhang J, Tong KL, Li PK, Chan AY, Yeung CK, Pang CC, Wong TY, Lee KC, Lo YM: Presence of donor- and recipient-derived DNA in cell-free urine samples of renal transplantation recipients: Urinary DNA chimerism. Clin Chem 1999;45:1741-1746. 